\title{
Preventing Sapsucker Damage on Sugar Maple (Acer saccharum)
}

\author{
E. Thomas Smiley, Donald C. Booth, and Liza W. Wilkinson
}

The yellow-bellied sapsucker (Sphyrapicus varius) is the primary cause of sapsucker damage on trees in the eastern United States (Ostry and Nicholls 1976). This migratory bird winters in the south and summers in northern states. In the Carolinas, U.S., the birds cause damage from November through March. Insects are a major part of this species diet; however, it is best known for making small wounds in stems and large branches and feeding on either phloem or xylem sap that oozes from the wounds. Phloem sap is the main source during the summer breeding season (Tate 1973; Eberhardt 2000), whereas xylem sap is more readily available from deciduous trees after leafdrop in the winter. Sapsuckers will test many trees and select only those that have the highest quality sap to feed on repeatedly. Sugar and amino acid levels are often highest on trees that have injuries that restrict sap movement (Kilham 1964; White 1984). Similarly, sapsuckers are thought to choose trees in poor health (Eberhardt 2000).

Symptoms of repeated feeding are horizontal rows of $1 \mathrm{~cm}$ ( $0.04 \mathrm{in})$ diameter holes in the bark. These wounds ooze sap that the bird feeds on. Excess sap may run down the surface of the bark and promote the growth of dark-colored fungi, a condition called "Black bark" (Minnesota Department of Natural Resources 1999). Insects and animals, including squirrels, porcupines, hummingbirds, ants, hornets, and wasps, are also attracted to this sap food source (Minnesota Department of Natural Resources 1997). Some of these may cause more damage to the tree.

Although most trees do not exhibit severe decline from sapsucker attack, some studies have found a loss of growth and crown dieback associated with severe girdling (Erdmann and Oberg 1974; Eberhardt, 2000). Sapsuckers have also been found to cause damage, which results in ring shake and the entrance of wood decay (Shigo 1963).

Wrapping trunks and branches with burlap is the traditional method to deter sapsucker wounds (Minnesota Department of Natural Resources 1999). However, no published studies could be found that quantify the effectiveness of this treatment. This study was undertaken to determine the effectiveness of two different trunk wrap materials, burlap and polypropylene tree wrap, for preventing sapsucker feeding.

\section{MATERIALS AND METHODS}

Fifteen sugar maples (Acer saccharum) with evidence of active sapsucker damage were selected at the Bartlett Tree Research Laboratories in Charlotte, NC, U.S. Mean trunk diameter measured at $1.4 \mathrm{~m}(4.6 \mathrm{ft})$ was $23.7 \mathrm{~cm}$ (9.5 in) with a standard deviation of 13.1 (5.1). Black electrical tape was used to divide affected tree trunks into three $60 \mathrm{~cm}$ (24 in) sections.

One of three treatments was randomly applied to each section on each tree on 9 February 2006. The treatments were:

1. Nontreated control;

2. Natural burlap fabric; and

3. Polypropylene tree trunk wrap $76 \mathrm{~mm}$ (3 in) wide (DeWitt, Sikeston, MO).

Burlap was cut into the largest piece that would cover an area of the trunk and stapled into place with T-32, $7.8 \mathrm{~mm}(0.31$ in) staples (Arrow Fastener Co., Saddle Brook, NJ). Edges of the burlap were overlapped approximately $2 \mathrm{~cm}(0.8 \mathrm{in})$ when multiple sections were used. The trunk wrap was spiraled around the trunk with approximately $25 \%$ overlap and stapled at both ends. Additional wrapping and stapling was used as needed to keep wraps close to the trunk and to reduce gaps around branches.

On each stem section, the numbers of "active" and "bleeding" wounds were counted on a weekly basis. Active wounds had exposed live phloem with no evidence of callus growth. Bleeding wounds had the characteristics of active wounds plus they had sap flowing from them (Figure 1). Trees were evaluated before treatment on 9 February 2006 after treatments were applied on 16 and 24 February and 3 and 10 


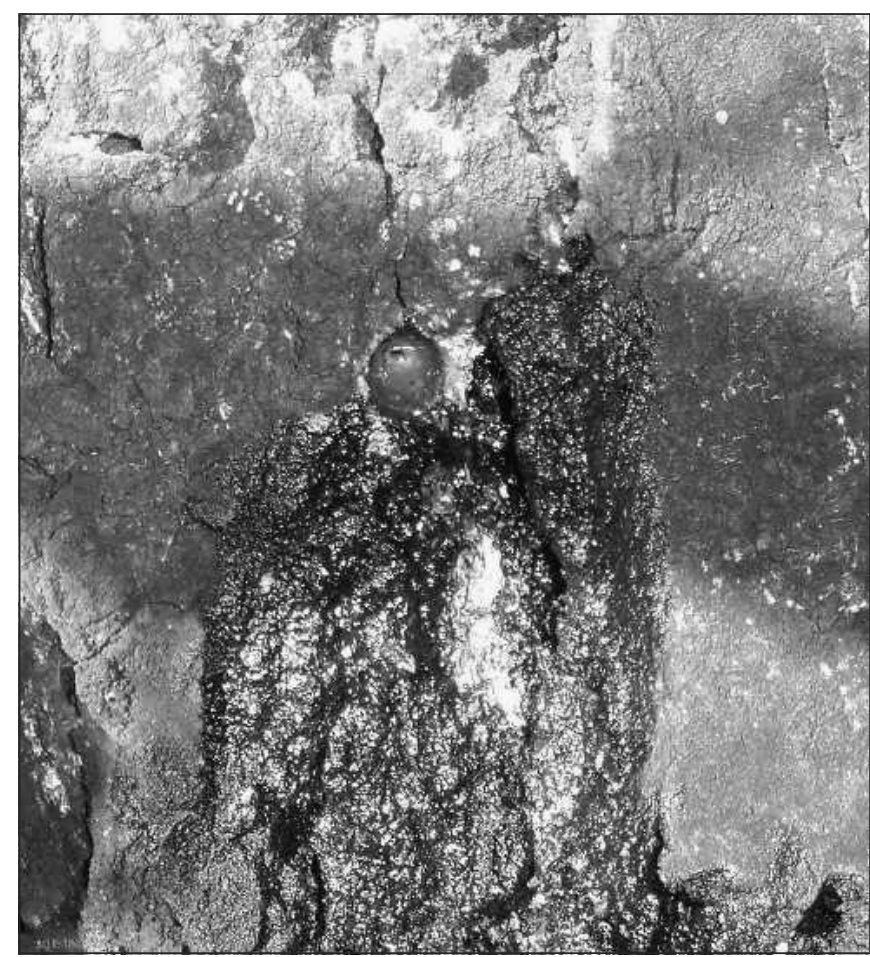

Figure 1. A bleeding wound in the bark of sugar maple (Acer saccharum) created by sapsucker (Sphyrapicus varius).

March 2006 by counting the active and bleeding wounds on each treated and untreated section of stem. After treatments were removed on 11 March 2006, all previously covered areas were inspected for the presence of previously undetected sapsucker damage.

Data were analyzed using an analysis of variance with separation of means using the Student Newman-Keuls procedures (SPSS, Chicago, IL; $P=0.05$ ).

\section{RESULTS}

Burlap was much faster to install and easier to work with than the tree trunk wrap. This was because of the larger pieces of burlap that could be used as well as the pliability of the burlap. With the tree wrap, there were many large gaps between the bark and the trunk that need to double-wrapped or fastened down with additional staples to reduce the gaps.

There were highly significant differences in the number of active and bleeding wounds between treatments and the controls. Both the tree wrap and burlap treatments completely prevented feeding by sapsuckers in the protected areas of the trees (Figures 2, 3, and 4). There were no significant differences in the number of bleeding wounds before treatment or at the 10 March count. No wounds were found under the burlap or trunk wrap after it was removed at the end of the trial.

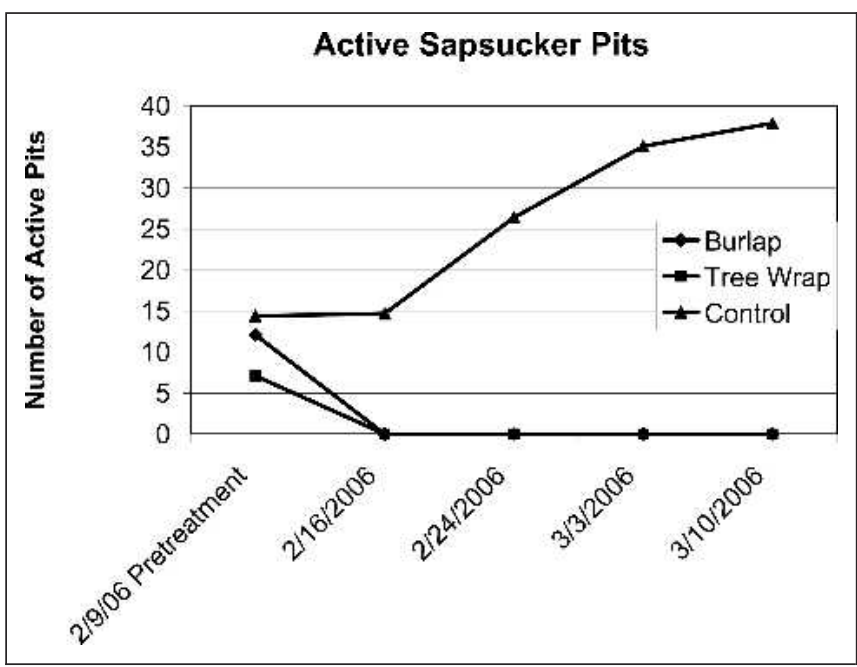

Figure 2. The number of active wounds created by Sphyrapicus varius before and after trunk wrapping treatments on $60 \mathrm{~cm}$ (24 in) sections of Acer saccharum stems. The mean number of wounds was significantly different after 16 February 2006.

\section{DISCUSSION}

The traditional trunk wrapping treatment for sapsuckers works extremely well to both stop ongoing attacks and prevent new damage. Increasing attacks on the control areas may indicate that the bird has changed its feeding habits, going from the treated area to the control area. This may have implications for susceptible trees near treated trees.

There are anecdotal reports that sapsuckers in the western United States are not deterred from damaging trees wrapped with burlap. A study of western sapsuckers is required to clarify the effectiveness of wrap treatments in that area.

It was thought that using a trunk wrap instead of burlap might speed the installation process and be more effective than burlap, but that did not turn out to be the case. Burlap was easier to install and remove, and both products were equally effective at preventing sapsucker damage.

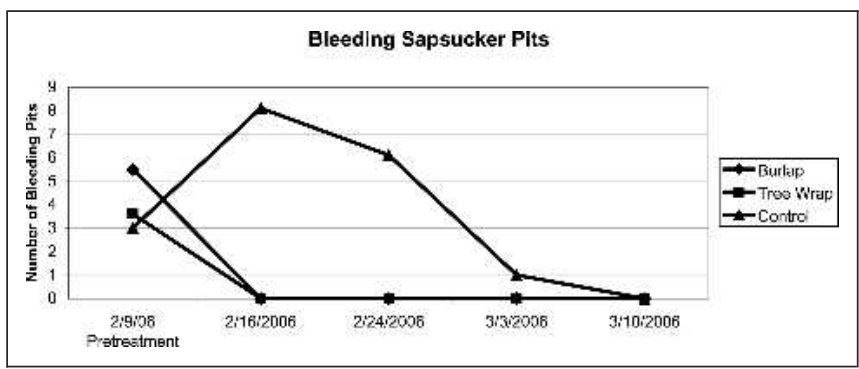

Figure 3. The number of bleeding wounds created by Sphyrapicus varius before and after trunk wrapping treatments on $60 \mathrm{~cm}$ (24 in) sections of Acer saccharum stems. 


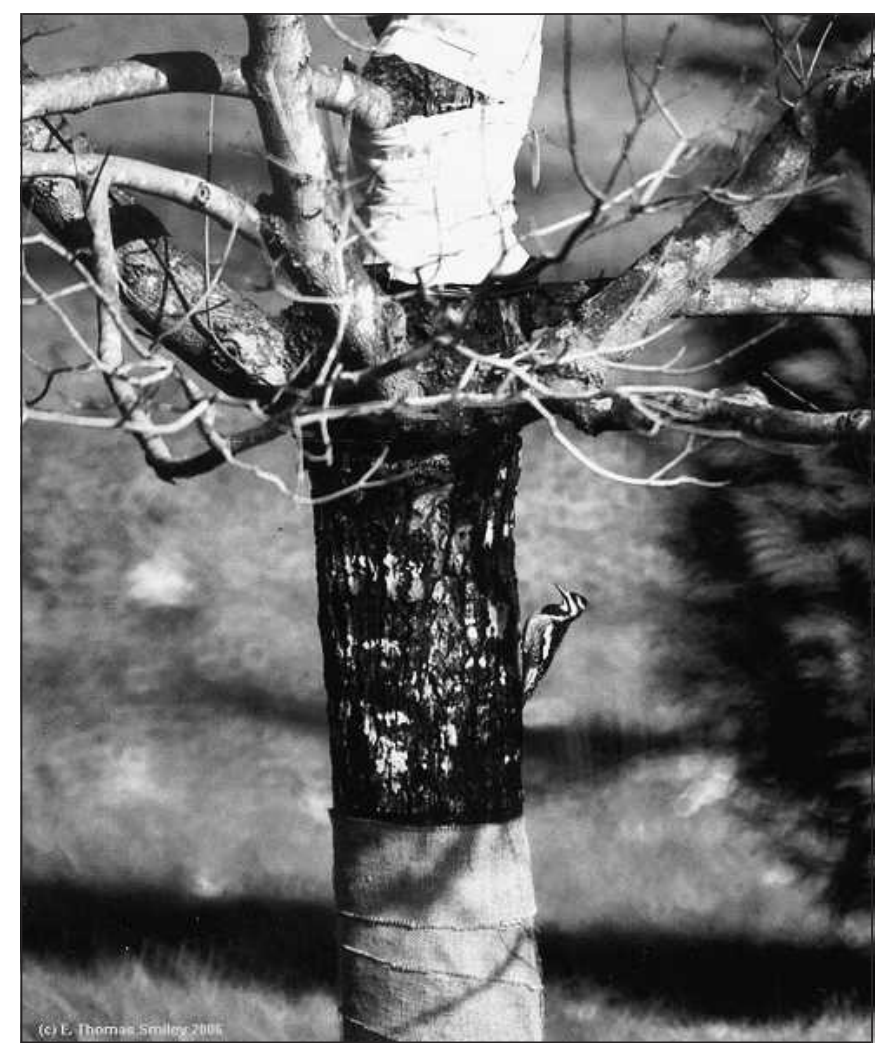

Figure 4. Sapsucker (Sphyrapicus varius) feeding on control treatment between tree wrap (top) and burlap (bottom) of Acer saccharum stem.

Although trunk wrapping did protect treated trees, it is a very time-consuming operation and the treatment could be considered unsightly by many consumers. Further study is needed to find effective treatments that can be applied more rapidly.

Acknowledgments. We express our appreciation to Robert A. Bartlett Jr. and the Bartlett Tree Expert Co. for their support of this research and to Bruce R. Fraedrich, Director of the Bartlett Tree Research Laboratories.

\section{LITERATURE CITED}

Eberhardt, L.S. 2000. Use and selection of sap trees by yellow-bellied sapsuckers. The Auk 117:41-51.

Erdmann, G.G., and R.R. Oberg. 1974. Sapsucker feeding damages crown-released yellow birch trees. Journal of Forestry 72:760-764.

Kilham, L. 1964. The relations of breeding yellow-bellied sapsuckers to wounded birches and other trees. The Auk 81:520-527.

Minnesota Department of Natural Resources. 1997. Animal Damage-Sapsucker Damage. Yellow-bellied Sapsucker. Forest Insect and Disease Newsletter. June 1997. The
Minnesota Department of Natural Resources web site (online). www.dnr.state.mn.us/fid/june97/06209714. html (accessed 10/26/2006).

. 1999. Yellow-bellied Sapsucker. Forest Insect and Disease Newsletter June 1999. The Minnesota Department of Natural Resources web site (online). www. dnr.state.mn.us/fid/june99/06019906.html (accessed 10/ 26/2006).

Ostry, M.E., and T.H. Nicholls. 1976. How to Identify and Control Sapsucker Injury on Trees. St. Paul, MN: U.S. Dept. of Agriculture, Forest Service, North Central Forest Experiment Station.

Shigo, A.L. 1963. Ring Shake Associated with Sapsucker Injury. U.S. Forest Service Research Paper NE-8.

Tate, J. 1973. Methods and annual sequence of foraging by the sapsucker. The Auk 90:840-856.

White, T.C. 1984. The abundance of invertebrate herbivores in relation to the availability of nitrogen in stressed food plants. Oecologia 63:90-105.

E. Thomas Smiley, PhD (corresponding author)

Arboricultural Researcher

Bartlett Tree Research Laboratories

Adjunct Professor

Clemson University

13768 Hamilton $R d$.

Charlotte, NC 28278, U.S.

tsmiley@bartlettlab.com

Donald C. Booth, PhD

Entomologist

Bartlett Tree Research Laboratories

13768 Hamilton $R d$.

Charlotte, NC 28278, U.S.

dbooth@bartlettlab.com

Liza W. Wilkinson

Research Technician

Bartlett Tree Research Laboratories

13768 Hamilton Rd.

Charlotte, NC 28278, U.S.

lwilkinson@bartlettlab.com

Résumé. Le pic maculé (Sphyrapicus varius) est la cause première de dommages aux arbres par les pics dans l'Est des ÉtatsUnis. Ces dommages peuvent tuer des branches entières, peuvent créer des portes d'entrée pour les champignons de carie ou encore des décollements des anneaux de croissance; tous pouvant conduire à des bris d'arbre. Ce test compare deux matériaux d'enveloppement des troncs sur 15 érables à sucre (Acer saccharum) en regard de leur 
efficacité face aux dommages par les pics. Les troncs ont été marqués sur trois sections de $60 \mathrm{~cm}$ chacune, et par la suite ils ont été emballés (toile d'emballage ou protecteur commercial de tronc) ou non. Les dommages par l'alimentation du pic ont été quantifiés à chaque semaine. Les deux matériaux ont permis de prévenir tout nouveau dommage dans les zones protégées. La toile d'emballage était à la fois plus facile à installer et à enlever que le protecteur commercial de tronc.

Zusammenfassung. Der gelbbauchige Saftsauger Sphyrapicus varius ist der primäre Grund für den Schaden an Bäumen in den östlichen Vereinigten Staaten. Diese Pest kann Äste töten, verursacht Eintrittssporten für Pilzsporen oder unterstützt Ringfäule, was alles zum Baumversagen führen kann. Diese Untersuchung vergleicht zwei Verpackungsmaterialien an den Stämmen von 15 Zuckerahornen auf ihre Effizienz gegen Saftsaugerschaden. Die Stämme wurden in drei $60 \mathrm{~cm}$ Sektionen markiert und mit Rupfen, Stam- mverband oder gar nicht behandelt. Beide Materialien verhinderten weiteren Befall in den geschützten Flächen. Rupfen war einfacher als der handelsübliche Baumverband $\mathrm{zu}$ installieren und $\mathrm{zu}$ entfernen.

Resumen. El succionador amarillo de savia (Sphyrapicus varius) es la causa primaria de daño en árboles en el este de los Estados Unidos. Este daño puede matar ramas completas, puede permitir la entrada de hongos de descomposición, o promover anillos estrechos; todo lo cual provocaría la falla del árbol. Este ensayo comparó dos materiales de envoltura de los troncos en 15 maples (Acer saccharum) y su eficacia contra el daño del chupador. Los troncos fueron marcados y cubiertos en tres secciones de $60 \mathrm{~cm}$ ( 2 foot), y se aplicaron los tratamientos. El daño del insecto fue calificado semanalmente. Ambos materiales previnieron del daño en las áreas protegidas. El material fue más fácil de instalar y remover que el comercialmente disponible para la envoltura de troncos. 